


\title{
Black Charcoal for Green and Scalable Wooden Electrodes for Supercapabatteries
}

\author{
Lianlian Liu, Sergej Masich, Emma M. Björk, Niclas Solin, and Olle Inganäs*
}

A green, though black, sustainable and low-cost carbon material—charcoal produced from wood-is developed for electricity storage. Charcoal electrodes are fabricated by ball-milling charcoal and adding protein nanofibril binders. The charcoal electrode presents a capacitance of $360 \mathrm{~F} \mathrm{~g}^{-1}$ and a conductivity of $0.2 \mathrm{~S} \mathrm{~m}^{-1}$. A pair of redox peaks is observed in the cyclic voltammetry and assigned to originate from quinone groups. Compared with other wooden electrodes, these charcoal electrodes display better cycling stability with $88 \%$ capacity retention after 1000 cycles. Their discharge capacity is 2.5 times that of lignosulfonate/graphite hybrid electrodes.

\section{Introduction}

The need for scalable and sustainable materials for electrical energy storage is widely recognized, and biological production of such materials is desirable. As the development of energy technology has always depended on the biological route, in the form of wood and plants for combustion, it is certainly of interest to evaluate the relevance of this class of green and sustainable materials also for electrical energy storage. We have previously demonstrated how waste products from the production of paper and pulp can be inserted in electrodes for charge storage, relying on the quinone groups formed from lignin in wood. ${ }^{[2]}$ The electroactive materials are formed from black liquor, in

\author{
L. Liu, N. Solin, O. Inganäs \\ Biomolecular and Organic Electronics \\ Department of Physics, Chemistry and Biology \\ Linköping University \\ SE 58183 Linköping, Sweden \\ E-mail: olle.inganas@liu.se \\ S. Masich \\ 3D-EM-Facility \\ Karolinska Institutet \\ SE171 77 Stockholm, Sweden \\ E. M. Björk \\ Nanostructured Materials \\ Department of Physics, Chemistry and Biology \\ Linköping University \\ SE 58183 Linköping, Sweden
}

The ORCID identification number(s) for the author(s) of this article can be found under https://doi.org/10.1002/ente.202101072.

(C) 2022 The Authors. Energy Technology published by Wiley-VCH GmbH. This is an open access article under the terms of the Creative Commons Attribution-NonCommercial License, which permits use, distribution and reproduction in any medium, provided the original work is properly cited and is not used for commercial purposes.

DOI: 10.1002/ente.202101072 combination with electronic polymers ${ }^{[1-3]}$ or graphite ${ }^{[4-7]}$ and other carbons. ${ }^{[3,8]}$ Reviews on the topic of organic electrode materials are widely available, ${ }^{[9]}$ on biomolecular-based electrodes less so, ${ }^{[3,10]}$ and on biopolymer-based materials extracted from waste flows even less so. ${ }^{[11]}$

The use of biological materials for making hard carbon electrodes by carbonization, for example, the anode in sodiumion batteries with capacities exceeding $300 \mathrm{mAh}^{-2}$, has been demonstrated for wood. ${ }^{[12]}$ The wood is thermally treated at $700-1000^{\circ} \mathrm{C}$, retains the microstructure from wood, and has a high electronic conductivity. Similarly, hard carbon from peat was treated by pre-pyrolysis at temperatures as low as $450^{\circ} \mathrm{C}$ and chemically cleaned, but then carbonized at $1400-1500^{\circ} \mathrm{C} .{ }^{[13]}$ These high-temperature routes to obtain hard carbons give sodium insertion materials of a rather high capacity $\left(200-300 \mathrm{mAh} \mathrm{g}^{-1}\right)$ at low charging rates. Moreover, activated carbon with a large surface area produced from biomass is also used for electricity storage, for example, in supercapacitors. ${ }^{[14]}$ They were usually prepared under 600 $900^{\circ} \mathrm{C}$ in the presence of active agents, with a capacitance of $90-400 \mathrm{~F} \mathrm{~g}^{-1} \cdot{ }^{[15]}$ The high conversion temperature, therefore, requires considerable energy investment in constructing these electrode materials.

Another sustainable form of carbon — charcoal—is generated by incomplete combustion of wood residues under oxygenlimited conditions and relatively low temperatures (400$\left.700^{\circ} \mathrm{C}\right) .{ }^{[16]}$ It is the form of carbons used to enable the industrial revolution in the 17-19th century, when charcoal was prepared to react with iron ore and form iron and steel. Charcoals generated by combustion in charcoal kilns were very common and contributed to the decline of forests in western Europe, where charcoal was essential for metal processing. Charcoal is these days often used for cooking and barbecue, but less so for metal processing. In addition, the use of charcoal as electrode and reagent was known to scientists such as Scheele and Humphry Davy in the 18 and 19th centuries. The electrical properties of charcoal were used by Alessandro Volta, who studied the electrochemical series of metals, with $\mathrm{Zn}$ electrodes and charcoal electrodes giving the highest electromotive force, as reported to the Royal Society of London in a letter in $1800 .{ }^{[17]}$

We here report the characterization of forms of charcoal, collected from charcoal pits. They were directly used as electrodes for supercapabatteries and outperform the more processed materials formed from black liquor in paper and pulp processing. Charcoal was historically produced by collecting wood and incinerating it under a mud layer in a kiln on the ground in a 
forest, year after year. We collected samples from a local charcoal source (Godegård, Östergötland) in April 2019, from a site where every year a charcoal kiln is built and operated. This is a social community activity, and the charcoal produced is sold for barbecues. We have very limited information on the thermal processing in this particular charcoal kiln, but know that it was built with birch logs and covered by mud, and was converted to charcoal over some days in the autumn of 2018.

The collected material gave surprisingly high conductance when probed by an ohmmeter in some cases, and in other cases were insulating. We had expected to see only insulating forms of burned wood, as the temperature of a charcoal kiln is documented to rise only to $500-600^{\circ} \mathrm{C}$. This should not, we expected, lead to complete graphitization of the wood into conducting material. Typically, graphitization or carbonization is done at temperatures of $700-1500{ }^{\circ} \mathrm{C}$, and mostly under better-controlled conditions than that of a pile of wood covered with mud.

We found that the more conducting charcoal samples, when ball milled and combined with protein nanofibril binders, gave electrodes with higher charge storage capacity than we have previously demonstrated with more elaborate means of processing better defined starting soluble materials from the paper and pulp routes of wood processing. As the simple thermal processing obliterates the need for extraction of lignin derivatives from black liquor in pulp mills and gives an insoluble form of electroactive materials with demonstrably less problems of loss of electroactivity by loss of active materials from electrodes, we consider this to be an easier, cheaper, and more scalable route to wooden electrodes. In this work, we emphasize the properties and capacity of these low-cost sustainable materials as applied in electricity storage. An important aspect of these materials is that in the kiln, the energy required for the conversion of wood to charcoal is supplied by combustion of some of the wood itself-accordingly, no external energy supply is needed. More studies on controlled processing of charcoal materials are beyond the scope of this work.

\section{Results and Discussions}

Two types of charcoal materials were used in this work: conducting charcoal and nonconducting charcoal. This classification is based on the simple measurements of resistance in the direction of wood fiber when contacting the charcoal piece with a twoelectrode multimeter. Some showed kiloohm resistance, and others gave resistance larger than 20 megohm. The samples were designated as "charcoal C" and "charcoal NC," respectively. The electrodes fabricated from charcoal materials and protein nanofibrils via mechanochemistry are designated as "charcoal C electrode" and "charcoal NC electrode." The characterizations were done with the raw charcoal materials, except for the Raman, scanning electron microscopy (SEM), transmission electron microscopy (TEM), and electrochemical measurements done on the charcoal electrodes after the ball-milling process.

\subsection{Chemical Composition}

The elemental analysis was performed on the two charcoal samples C and NC, with carbon, hydrogen, nitrogen, sulphur
Table 1. Elemental analysis results of charcoal $C$ and charcoal NC.

\begin{tabular}{lcc}
\hline Element & Charcoal C [wt\%] & Charcoal NC [wt\%] \\
\hline $\mathrm{C}$ & 80.18 & 90.57 \\
$\mathrm{H}$ & 3.53 & 1.30 \\
$\mathrm{~N}$ & 0.59 & 0.35 \\
$\mathrm{O}$ & 13.76 & 3.41 \\
$\mathrm{O} / \mathrm{C}^{\mathrm{a})}$ & 0.13 & 0.03 \\
$\mathrm{H} / \mathrm{C}^{\mathrm{a})}$ & 0.53 & 0.17 \\
\hline
\end{tabular}

${ }^{\text {a) }} a$ : atomic ratio.

(CHNS) analysis using Dumas combustion method and O analysis using Unterzaucher pyrolysis method. The results are shown in Table 1, where charcoal C shows a lower carbon fraction than $\mathrm{NC}$, and charcoal $\mathrm{C}$ contains a higher $\mathrm{O} / \mathrm{C}$ and $\mathrm{H} / \mathrm{C}$ atomic ratio than charcoal NC.

The Fourier transform infrared (FTIR) spectra of charcoal C and charcoal NC were collected (Figure 1) to clarify what chemical bonds exist in the samples. Charcoal NC exhibits the $\mathrm{O}-\mathrm{H}$ stretch band at $3437 \mathrm{~cm}^{-2}, \mathrm{C}=\mathrm{O}$ stretching vibration at $1693 \mathrm{~cm}^{-2}$; vibration of aromatic rings at 1589 and $1431 \mathrm{~cm}^{-2}$; $\mathrm{C}-\mathrm{O}-\mathrm{C}$ stretching vibrations at 1378 and $1260 \mathrm{~cm}^{-2}$; a band at $874 \mathrm{~cm}^{-2}$ corresponding to $\mathrm{C}-\mathrm{H}$ bending vibration. The band at $\approx 2400 \mathrm{~cm}^{-2}$ is due to the residual carbon dioxide in the system. Charcoal C shows less significant absorption at 3437, 1640, 1431, 1042 , and $874 \mathrm{~cm}^{-2}$, ascribed to the $\mathrm{O}-\mathrm{H}$ stretch band, $\mathrm{C}=\mathrm{O}$ stretching vibration, aromatic rings vibration, $\mathrm{C}-\mathrm{O}-\mathrm{C}$ stretching vibration, and $\mathrm{C}-\mathrm{H}$ bending vibration, respectively. These results prove the presence of oxygen functional groups, which are consistent with the elemental analysis results shown in Table 1.

The X-ray diffraction (XRD) measurements were obtained to study the crystalline structures of these charcoal samples. In Figure 2, neither charcoal C (in electrode and powder) nor charcoal NC (in electrode and powder) shows narrow diffraction peaks. However, the powder XRD patterns of charcoal $\mathrm{C}$ display broad peaks at $2 \theta \approx 23^{\circ}$ and $2 \theta \approx 44^{\circ}$, which can be indexed to (002) and (101) graphitic planes, respectively, similar to what is reported for hard carbon. ${ }^{[18]}$ However, the powder XRD patterns with low intensity in charcoal $\mathrm{C}$ characterize limited graphitic carbon, and the relatively featureless patterns of charcoal NC indicate amorphous carbon containing few (if any) graphitic domains. ${ }^{[19]}$

The non-graphitic structures of these charcoal samples were further probed via Raman measurements, with the Raman spectroscopy results shown in Figure 3. The pristine graphite features bands at 1346,1577 , and $2715 \mathrm{~cm}^{-2}$, ascribed to the D, G, and 2D bands, respectively. Both charcoal $\mathrm{C}$ and charcoal NC present bands at 1340 and $1592 \mathrm{~cm}^{-2}$, and also show a broad band at $2500-3000 \mathrm{~cm}^{-2}$. The former two bands can be treated as D and $\mathrm{G}$ bands, which are ascribed to the breathing modes of $\mathrm{sp}^{1}$ atoms in rings (disordered carbon), and the in-plane vibrational mode and bond stretching of paired $\mathrm{sp}^{1}$ atoms in rings and chains (graphitic domains), respectively. Moreover, the intensity ratio of $\mathrm{D}$ and $\mathrm{G}$ bands $\left(I_{\mathrm{D}} / I_{\mathrm{G}}\right)$, which is inversely proportional to the crystallite size and disorder, was calculated for graphite and charcoal samples. The $I_{\mathrm{D}} / I_{\mathrm{G}}$ ratios for graphite, charcoal $\mathrm{C}$, and charcoal NC are $0.14,1.01$, and 0.73 , respectively. The $I_{\mathrm{D}} / I_{\mathrm{G}}$ of 

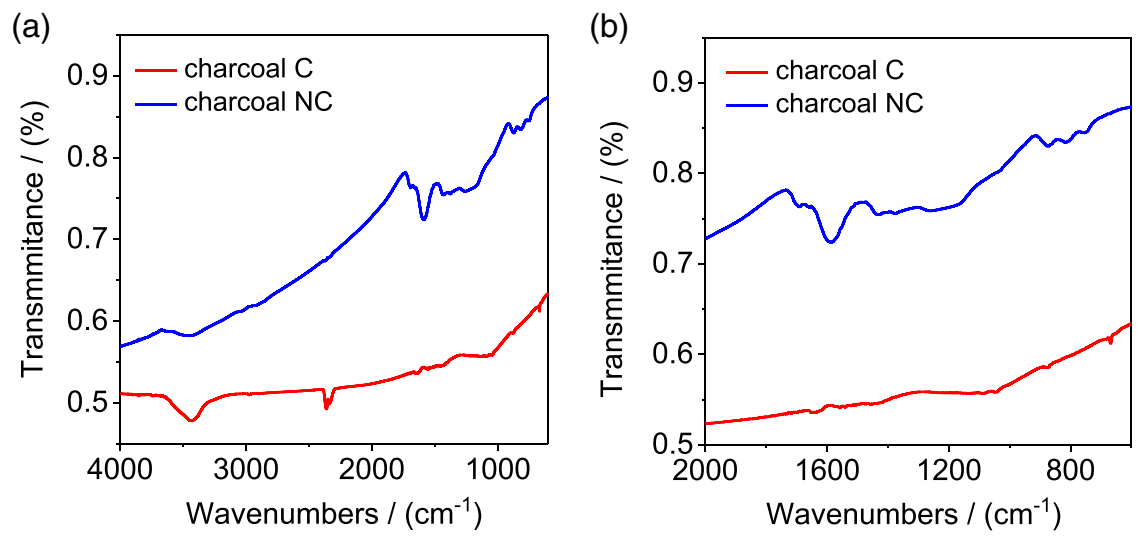

Figure 1. a,b) FTIR transmittance spectra of charcoal C and charcoal NC.
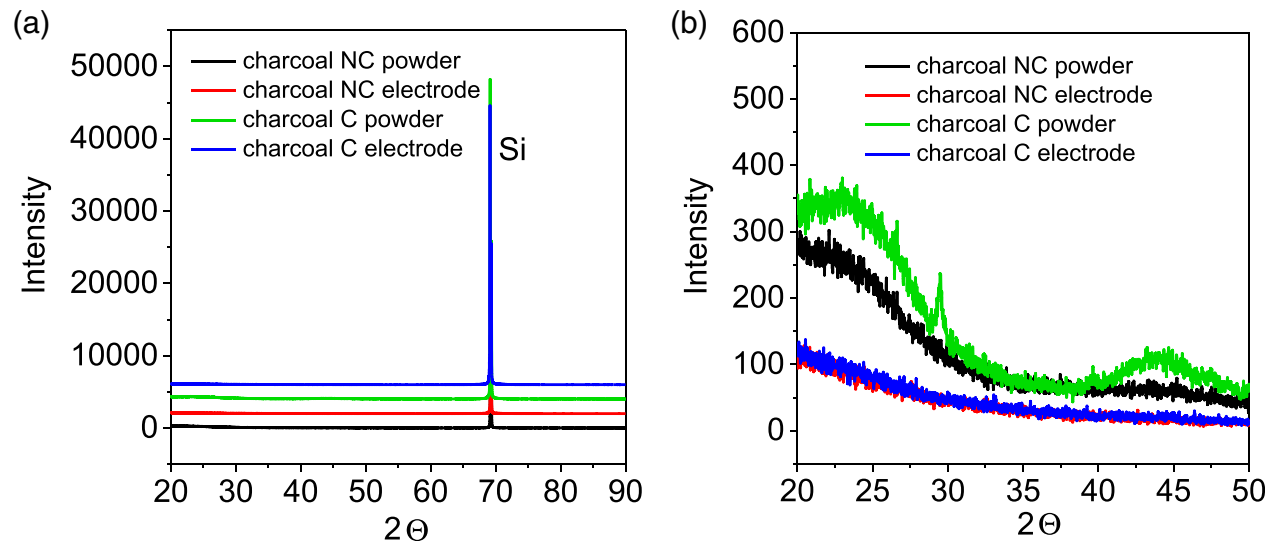

Figure 2. a,b) Powder XRD patterns of charcoal $C$ and charcoal NC and XRD patterns of charcoal $C$ electrode and charcoal NC electrode.

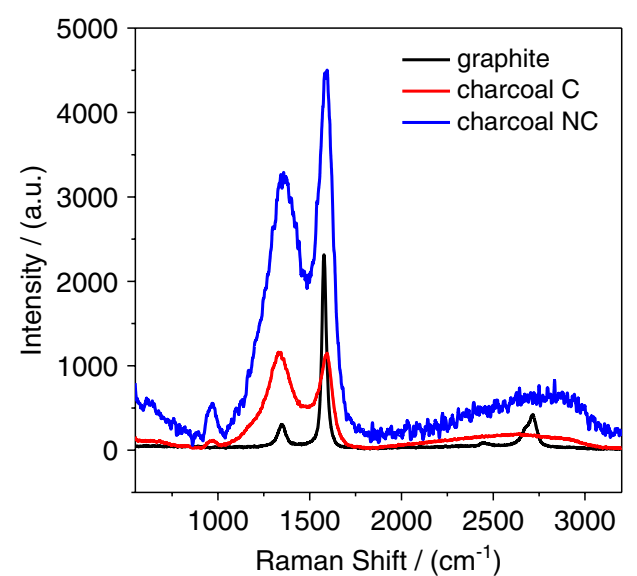

Figure 3. Raman spectra of graphite, charcoal $C$, and charcoal NC.

0.73 and 1.01 in charcoal materials are in agreement with the limited graphitic nature of carbons; the higher $I_{\mathrm{D}} / I_{\mathrm{G}}$ for charcoal $\mathrm{C}$ probes a greater disruption of graphitic domains, which can result from the different levels of carbonization. ${ }^{[19]}$ In addition, charcoal $\mathrm{C}$ exhibits smaller crystallite size and more disorder than charcoal NC. In general, these Raman results are consistent with the XRD patterns, suggesting limited graphitic nature of carbon and different levels of carbonization in charcoal $\mathrm{C}$ and charcoal NC materials.

The thermogravimetric analysis (TGA) was executed to study the thermal stability of these charcoal materials under $\mathrm{N}_{2}$, as shown in Figure 4. The TGA curve of charcoal $\mathrm{C}$ presents a drop at $117^{\circ} \mathrm{C}$ due to the evaporation of water. Subsequently, it stays stable until $650{ }^{\circ} \mathrm{C}$ with a residual mass ratio of $92 \%$ and a final residual mass ratio of $87.3 \%$ at $1000^{\circ} \mathrm{C}$. The TGA curve of charcoal $\mathrm{C}$ between 650 and $1000^{\circ} \mathrm{C}$ is consistent with that of lignin, ${ }^{[20]}$ whose degradation takes place through $160-900^{\circ} \mathrm{C}$. Accordingly, it indicates a degradation of the residual lignin in the charcoal material. However, charcoal NC stays stable until $460{ }^{\circ} \mathrm{C}$, and then a degradation occurs in the region between 460 and $750^{\circ} \mathrm{C}$, which is ascribed to the degradation of cellulose, hemicellulose, and lignin; ${ }^{[20,21]}$ it shows a final residual mass ratio of $79 \%$ at $1000^{\circ} \mathrm{C}$. Charcoal $\mathrm{C}$ shows higher thermal stability than charcoal NC.

\subsection{Porosity}

Nitrogen sorption analysis was used to measure the porosity of the charcoal materials. Charcoal $\mathrm{C}$ presents a surface area of 


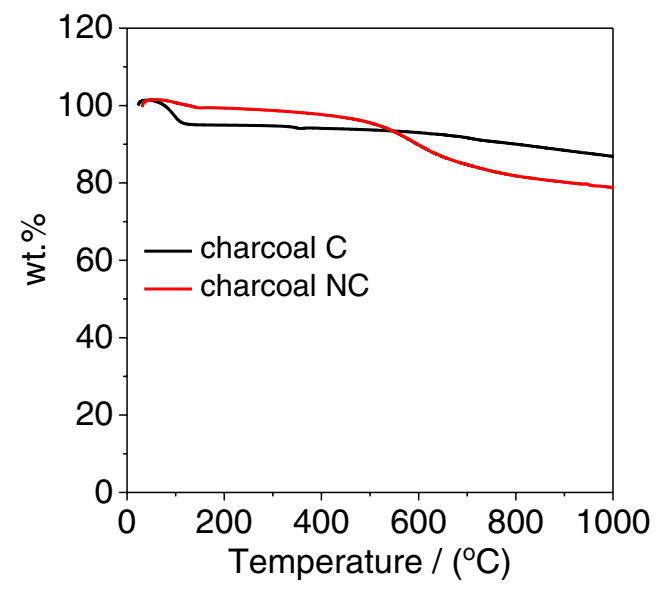

Figure 4. TGA results of charcoal $C$ and charcoal $N C$ at a heating rate of $\mathrm{min}^{-1}$ under Ar atmosphere.

$332 \mathrm{~m} \mathrm{~g}^{-1}$ and a micropore volume of $0.10 \mathrm{~cm}^{3} \mathrm{~g}^{-1}$; charcoal NC exhibits a larger surface area of $440 \mathrm{~m}^{2} \mathrm{~g}^{-1}$ and a higher micropore volume of $0.16 \mathrm{~cm}^{3} \mathrm{~g}^{-1}$ (as summarized in Table 4). The isotherms, which are of type II, and pore size distributions of charcoal $\mathrm{C}$ and charcoal NC are shown in Figure S1, Supporting Information. The materials exhibit microporosity, as can be observed in the pore size distribution, as well as macroporosity from the voids between particles, as can be observed in the following electron micrographs. Moreover, in the pore size distributions from 1 to $10 \mathrm{~nm}$ (as shown in the inserted images in Figure S1b,d, Supporting Information), there are peaks at $\approx 2.5 \mathrm{~nm}$ for both materials.

The SEM images of charcoal $\mathrm{C}$ and charcoal NC electrodes (Figure 5a,b) indicate that charcoal C electrode presents a particle size range of 200-600 nm; charcoal NC electrode shows a larger particle size range of $200 \mathrm{~nm}-1 \mu \mathrm{m}$. These results agree with the Raman results that charcoal $\mathrm{C}$ has a smaller particle size range.

To image the internal structure of the charcoal particles observed by SEM, TEM was used with the charcoal electrode samples in a very diluted form, collected on TEM grids. Electrode samples with the protein nanofibrils (PNF) show the presence of long wire-like objects, as seen in Figure $5 c$, under defocusing conditions. In Figure 5d,e, particles of charcoal $\mathrm{NC}$ and charcoal C samples are imaged, respectively. They show inhomogeneity, with domains of higher scattering power within and at the boundary of particles. By tilting, electron reflection from some of these domains indicates crystallinity, verifying the results from XRD (vide supra).

\subsection{Electrochemical Measurements}

From the cyclic voltammetry $(\mathrm{CV})$ of the charcoal $\mathrm{C}$ electrode (Figure 6a), a pair of redox peaks is found at 0.37 and $0.1 \mathrm{~V}$ versus $\mathrm{Ag} / \mathrm{AgCl}$, respectively, together with a capacitive response. Additionally, after the charge-discharge measurement, the current at the peaks increases (Figure 6a). This indicates that there are redox-active groups present in charcoal $\mathrm{C}$, which were activated during the electrochemical process. The CV of the NC electrode does not show any such structure, nor capacitance, as it is not conducting (Table 4). Moreover, the CV of charcoal C electrodes was scanned at various scan rates, as shown in Figure 6b. The peak current displays a linear relationship versus the scan rate in the range (Figure S2, Supporting Information), indicating no diffusion limitations in the charcoal electrode.

The discharge capacity of the charcoal $\mathrm{C}$ electrode was calculated to be $90 \mathrm{mAh} \mathrm{g}^{-2}$, based on Equation (1) and the charge-discharge plot in Figure 6c; it displays a discharge capacity retention of $88 \%$ after 1000 charge-discharge cycles (Figure 6d).

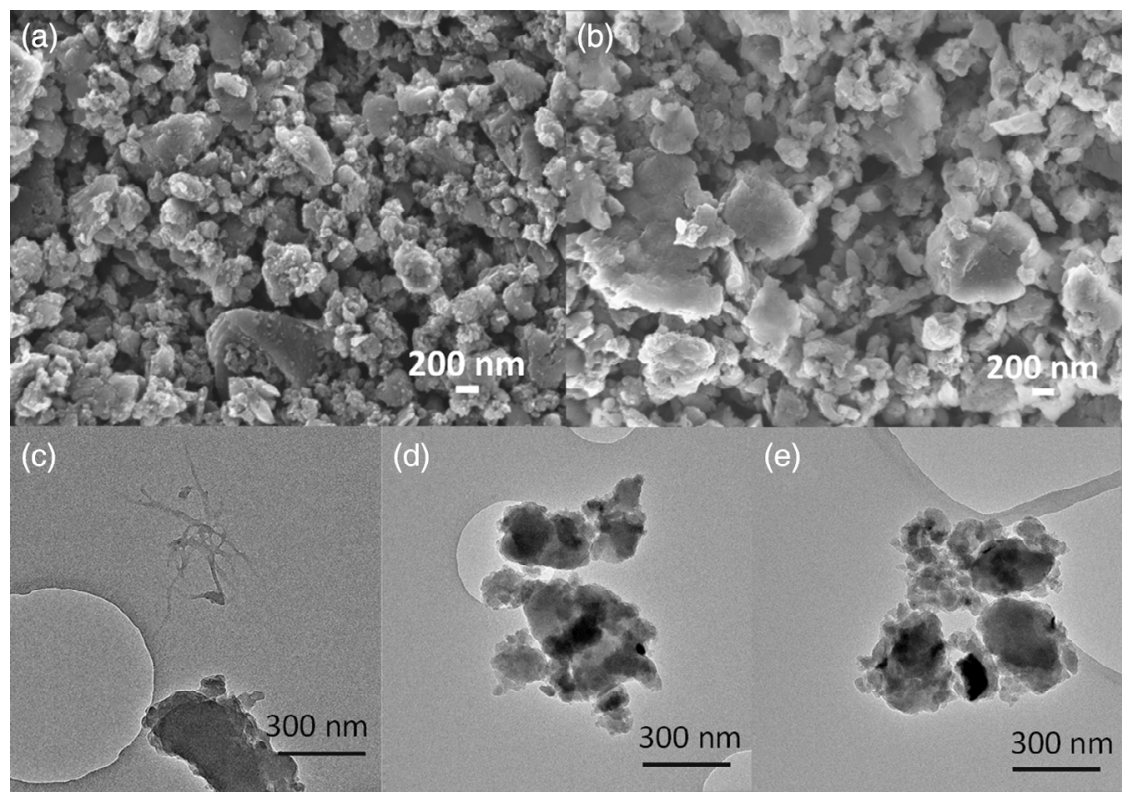

Figure 5. SEM images of a) charcoal $C$ and b) charcoal NC. TEM of c) charcoal NC mixed with PNF dispersion (50 wt $\%$ ), d) charcoal NC, and e) charcoal C. 
(a)

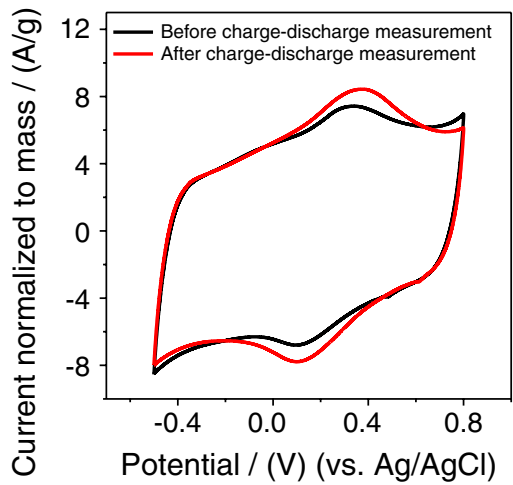

(c)

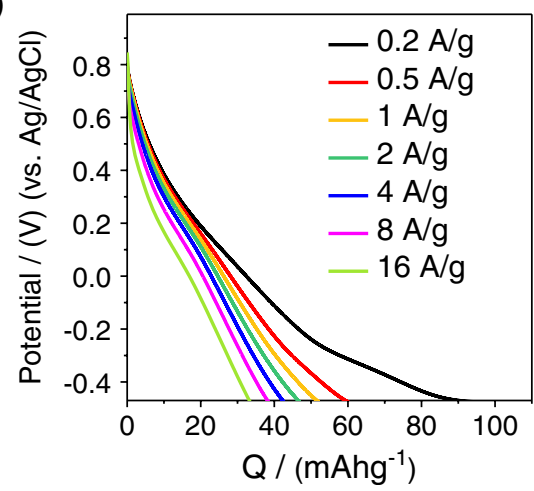

(b)

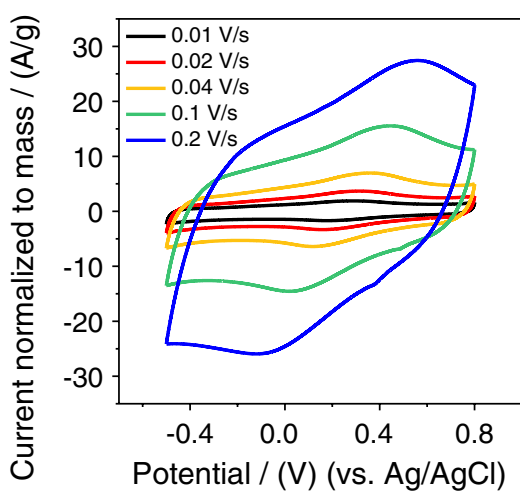

(d)

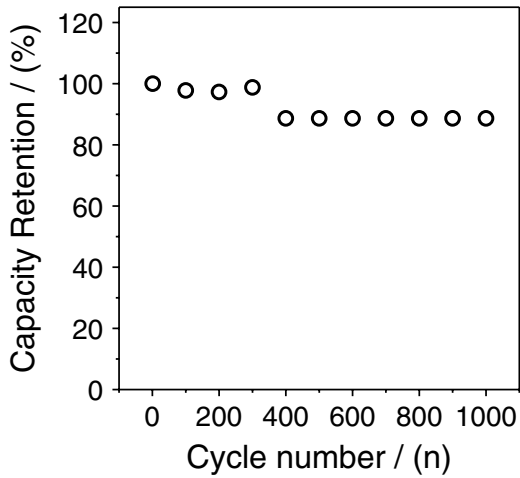

Figure 6. a) $\mathrm{CV}$ at the potential range of $-0.5-0.8 \mathrm{~V}$ at $0.05 \mathrm{~V} \mathrm{~s}^{-1}$ before and after charge-discharge measurements, b) $\mathrm{CVs}$ at various scan rate, c) discharge plots at various charge rate, and d) discharge capacity retention after reversible charge-discharge cycles at $4 \mathrm{Ag}^{-1}$, of charcoal $\mathrm{C}$ electrodes in $0.1 \mathrm{M} \mathrm{HClO}_{4}$.

The chemical species causing this redox activity could be quinone structures (due to the lignin). We have, therefore, attempted to follow the variation of this redox wave with different $\mathrm{pH}$ in the electrolyte, as shown in Figure 7a, but are only able to do so in the narrow $\mathrm{pH}$ interval of $1-2$, where the wave can be observed. At higher $\mathrm{pH}$, no distinct redox process can be observed, but $\approx 50 \%$ of the capacity remains. When plotting the redox potential, which was calculated based on the mid-peak potential of redox peaks, ${ }^{[22]}$ versus $\mathrm{pH}$ (in Figure $7 \mathrm{~b}$ ), it displays a

(a)

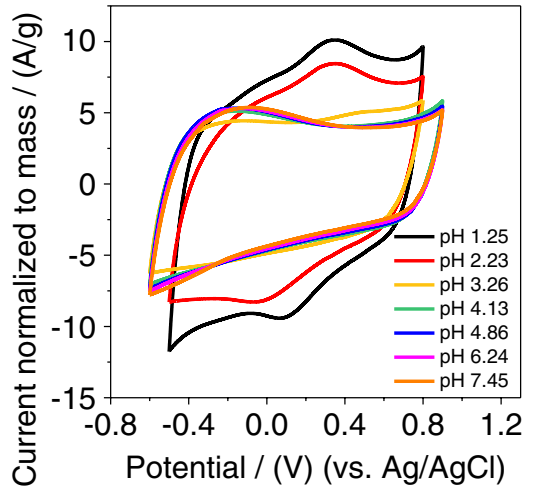

slope of $-64 \mathrm{mV} \mathrm{pH}^{-1}$. This is close to the theoretical Nernstian value of $-59 \mathrm{mV} \mathrm{pH}^{-1}$, for the two-electron and two-proton redox reactions of quinones. ${ }^{[23]}$ The redox reactions in the charcoal electrodes could thus be due to the quinone structures in lignin.

However, the redox potential in the charcoal electrode is different from that of the soluble quinone/hydroquinone in water. We demonstrate this by using the charcoal electrode in solutions of hydroquinone with concentrations from 0 to $50 \mathrm{mM}$. With

(b)

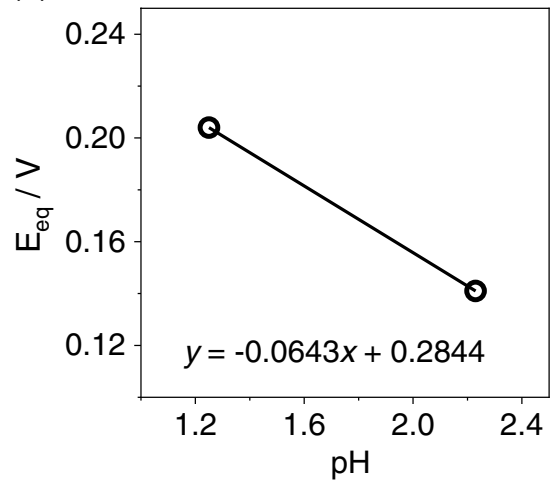

Figure 7. a) $\mathrm{CV}$ of charcoal $\mathrm{C}$ electrodes at various $\mathrm{pH}$ at a scan rate of $0.05 \mathrm{~V} \mathrm{~s}^{-2}$; b) the relationship of equilibrium potential $\left(E_{\mathrm{eq}}\right)$ versus $\mathrm{pH}$ in $\mathrm{HClO}{ }_{4}$ with different concentrations. 
increasing concentrations of hydroquinone and increasing currents, it is getting more and more difficult to discern the two contributing redox waves of soluble hydroquinone and charcoal redox groups, respectively, as shown in Figure S3, Supporting Information. At low concentrations and speeds, these processes are however possible to discern. We, therefore, suggest that the redox reaction in the solid electrode is due to a quinone with a small shift of the redox potential.

Given the source of the material, the most probable source of the redox group is residual lignin in carbon species. However, to exclude the possibility of a contributing redox process from the other elements of the charcoal electrode, we measured the fraction of metals in the charcoal material. There are several metals present in charcoal that can undergo redox reactions at the potential window of $-0.5-0.8 \mathrm{~V}$ versus $\mathrm{Ag} / \mathrm{AgCl}$.

The concentrations of metals in the charcoal materials were analyzed by inductively coupled plasma optical emission spectrometry (ICP-OES) (for $\mathrm{P}, \mathrm{K}, \mathrm{Ca}, \mathrm{Cu}, \mathrm{Mg}, \mathrm{Si}, \mathrm{Fe}$, and $\mathrm{Zn}$ ) and inductively coupled plasma mass spectrometry (ICP-MA) (for $\mathrm{Pb}$ ), and the results are shown in Table 2. In both charcoal $\mathrm{C}$ and charcoal NC, the three elements with the largest amount are $\mathrm{Ca}, \mathrm{K}$, and $\mathrm{Mg}$. Charcoal C contains $5 \mathrm{mg} \mathrm{kg}^{-1}$ of copper $(\mathrm{Cu})$, $100 \mathrm{mg} \mathrm{kg}^{-1}$ of iron (Fe), and $2 \mathrm{mg} \mathrm{kg}^{-1}$ of lead (Pb), whose standard potentials are closed to 0.1 or $0.37 \mathrm{~V}$ versus $\mathrm{Ag} / \mathrm{AgCl}$. However, the amount of these metals is too low to exhibit the redox peaks in the $\mathrm{CV}$. Accordingly, the redox peaks in the $\mathrm{CV}$ must originate from a carbon source.

As charcoal NC material is not conducting, it merely exhibits a discharge capacity of $0.55 \mathrm{~mA} \mathrm{hg}{ }^{-2}$. To improve the conductivity, graphite was ball milled with charcoal NC to fabricate the charcoal $\mathrm{NC}$ /graphite hybrid electrodes, with varying stoichiometry $(1 / 1,2 / 1,3 / 1,4 / 1$, by wt $\%)$. These charcoal NC/graphite electrodes display a discharge capacity range of $65-85 \mathrm{~mA} \mathrm{hg}^{-2}$ and a pair of redox peaks at $\approx 0$ and $\approx 0.5 \mathrm{~V}$, versus $\mathrm{Ag} / \mathrm{AgCl}$, as shown in Table 3 and Figure 8. These charcoal NC/graphite electrodes exhibit more pronounced redox peaks than charcoal $\mathrm{C}$ electrodes, and the CV shapes of charcoal C and charcoal NC/graphite electrodes are relatively different, due to their different nanostructures.

The source of the redox peaks observed in the charcoal is to be found in both charcoal C and NC variants, as demonstrated by adding graphite to enhance conductivity in charcoal NC. Plausible candidates for these redox peaks are the $\mathrm{C}=\mathrm{O}$ species found in the FTIR spectroscopy, though more visible in the

Table 2. ICP-OES and ICP-MS results of charcoal $C$ and charcoal NC.

\begin{tabular}{lcc}
\hline Element & Charcoal C $\left[\mathrm{mg} \mathrm{kg}^{-1}\right]$ & Charcoal $\mathrm{NC}\left[\mathrm{mg} \mathrm{kg}^{-1}\right]$ \\
\hline $\mathrm{P}$ & 360 & 440 \\
$\mathrm{~K}$ & 1900 & 1900 \\
$\mathrm{Ca}$ & 3000 & 3700 \\
$\mathrm{Cu}$ & 5 & 5 \\
$\mathrm{Mg}$ & 670 & 900 \\
$\mathrm{Si}$ & 120 & 260 \\
$\mathrm{Fe}$ & 100 & 220 \\
$\mathrm{Zn}$ & 96 & 35 \\
$\mathrm{~Pb}$ & 2 & $<1$ \\
\hline
\end{tabular}

Table 3. Redox peaks in $\mathrm{CV}$ and discharge capacity of charcoal NC/ graphite hybrid electrodes.

\begin{tabular}{lccc}
\hline $\begin{array}{l}\text { Charcoal } \mathrm{NC} / \\
\text { graphite hybrid } \\
\text { electrodes }\end{array}$ & $\begin{array}{c}\text { Discharge } \\
\text { capacity in } \\
{\left[\mathrm{mAh} \mathrm{g}^{-1}\right]}\end{array}$ & $\begin{array}{c}\text { Reduction peak } \\
\text { in } \mathrm{CV} \text { in }[\mathrm{V}] \\
\text { [versus } \mathrm{Ag} / \mathrm{AgCl}]\end{array}$ & $\begin{array}{c}\text { Oxidation peak } \\
\text { in } \mathrm{CV} \text { in }[\mathrm{V}] \\
{[\text { versus } \mathrm{Ag} / \mathrm{AgCl}]}\end{array}$ \\
\hline $1 / 1^{\text {a) }}$ & 65 & -0.06 & 0.56 \\
$2 / 1$ & 85 & -0.03 & 0.51 \\
$3 / 1$ & 73 & -0.02 & 0.51 \\
$4 / 1$ & 70 & -0.06 & 0.57 \\
\hline
\end{tabular}

a) a: stoichiometry (wt\%) of charcoal NC and graphite.

charcoal NC than in the charcoal C. The infrared spectrum is taken in transmission mode and with a considerable reflection of IR light in the metallic graphitic elements found in the charcoal. Therefore, the net result of transmission showing molecular vibrations, and reflection, without distinct molecular vibrations, can be rather varying for an inhomogeneous material. As noted in the TEM images, the charcoal particles are inhomogeneous on a small scale, with dense graphitic-like domains distributed in the core and in the edges of particles. This also agrees with the XRD results that show the presence of hard carbon in charcoal C.

The presence of a redox peak and a capacitance classifies this electrode as suitable for a redox supercapacitor. As hard carbons are favorite materials for sodium insertion batteries, we note here that the redox process is far away from the electrochemical window for sodium insertion in hard carbons, but also that such insertion reactions can hardly be occurring in the fast response supercapacitor functions demonstrated at high charging rates and fast voltammetry in an aqueous environment.

The physical parameters of charcoal $\mathrm{C}$ and charcoal NC electrodes, and other biomass-derived carbon materials are further summarized in Table 4. These two charcoal materials show different electrochemical properties, and more investigation is accordingly needed for a better understanding of these charcoal materials. We observe that charcoal NC has a higher specific surface area than charcoal $\mathrm{C}$, which indicates a higher number of active sites. However, charcoal NC also has a higher micropore volume, and diffusion of ions in micropores is strongly limited, which can explain the lower efficiency.

Carbonization without activation agents is commonly used to prepare active carbon materials, and one-step carbonization of biomass is demonstrated, as reviewed in previous studies. ${ }^{[15,24]}$ For example, lignosulfonate and lotus were used for the preparation of porous carbon without adding activation agents, as shown in Table 4. Carbon materials with a surface area over $2000 \mathrm{~m} \mathrm{~g}^{-1}$ and micropore volume of $0.5-1.5 \mathrm{~cm}^{3} \mathrm{~g}^{-1}$ can give a specific capacitance of $100-400 \mathrm{~F} \mathrm{~g}^{-1}$. Comparing this to charcoal $\mathrm{C}$ with a surface area of $330 \mathrm{~m}^{2} \mathrm{~g}^{-1}$ and micropore volume $0.1 \mathrm{~cm}^{3} \mathrm{~g}^{-1}$, a discharge capacity of $90 \mathrm{mAh} \mathrm{g}{ }^{-2}$ equals $250 \mathrm{~F} \mathrm{~g}^{-1}$. Charcoal NC, with a surface area of $440 \mathrm{~m}^{2} \mathrm{~g}^{-1}$, gives a discharge capacity of $130-88 \mathrm{mAh} \mathrm{g}^{-1}$ based on the mass of active material excluding graphite (Table 3), equals 360-244 $\mathrm{F} \mathrm{g}^{-1}$. Thus, these charcoal materials are competitive in electricity storage compared with other carbon materials, typically obtained at much higher 
(a)

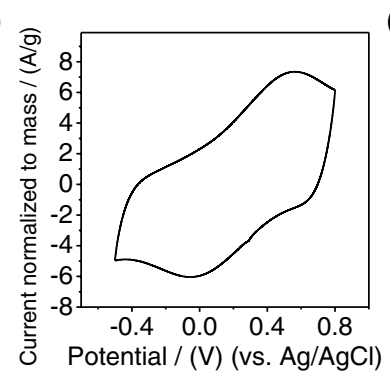

(e)

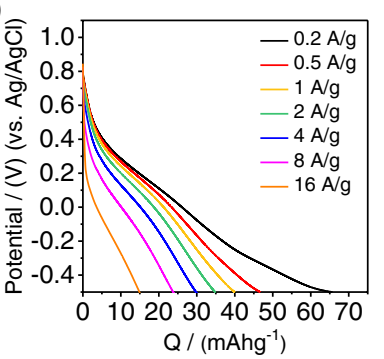

(b)

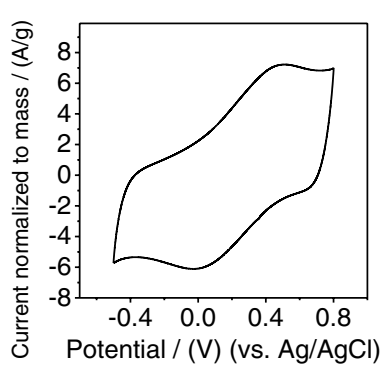

(c)

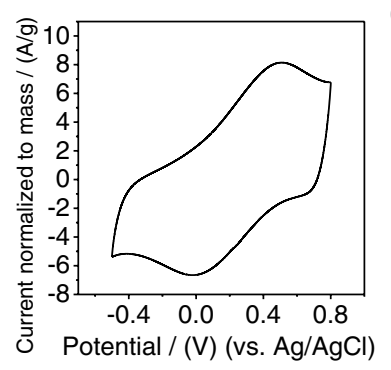

(d)

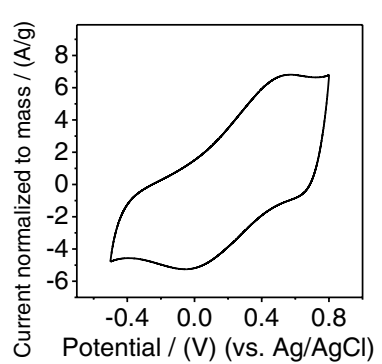

(f)

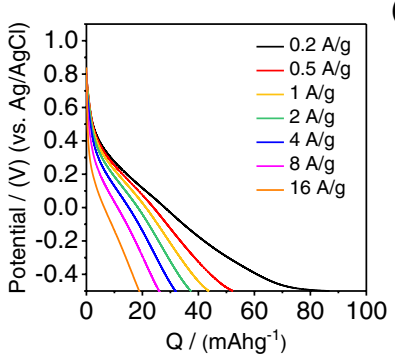

(g)

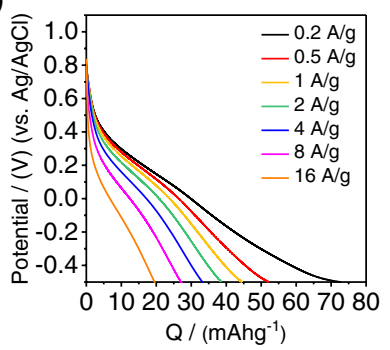

(h)

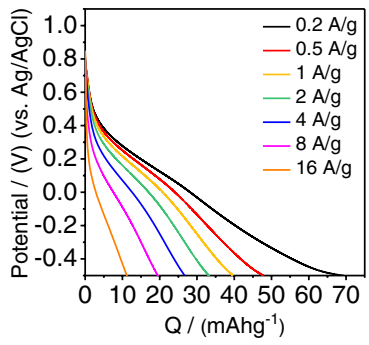

Figure 8. $\mathrm{CV}$ at $0.05 \mathrm{~V} \mathrm{~s}^{-1}$ and galvanostatic discharge plots at various charge rates of charcoal NC/graphite: a,e) $\left.\left.1 / 1 \mathrm{wt} \%, \mathrm{~b}, \mathrm{f}\right) 2 / 1 \mathrm{wt} \%, \mathrm{c}, \mathrm{g}\right) 3 / 1 \mathrm{wt} \%$, and d,h) $4 / 1 \mathrm{wt} \%$ in $0.1 \mathrm{M} \mathrm{HClO}_{4}$.

Table 4. Comparison of some parameters of charcoal C and charcoal NC electrodes, and other biomass-derived carbon materials.

\begin{tabular}{lccccc}
\hline & Thickness $[\mu \mathrm{m}]$ & $\begin{array}{c}\text { Electrical conductivity } \\
{\left[\mathrm{S} \mathrm{m}^{-1}\right]}\end{array}$ & $\begin{array}{c}\text { Discharge capacity/ } \\
\text { capacitance }\end{array}$ & $\begin{array}{c}\text { Surface area } \\
{\left[\mathrm{m}^{2} \mathrm{~g}^{-1}\right]}\end{array}$ & $\begin{array}{c}\text { Micropore volume } \\
{\left[\mathrm{cm}^{3} \mathrm{~g}^{-1}\right]}\end{array}$ \\
\hline Charcoal C & $6.2 \pm 0.3$ & $0.19 \pm 0.02$ & $90 \pm 1 \mathrm{mAh} \mathrm{g}^{-1}$ & 332 & 0.10 \\
Charcoal NC & $9.7 \pm 0.6$ & - & - & 440 & 0.16 \\
Lignin-derived carbon $^{[25]}$ & - & - & - & 574 & 0.18 \\
Lotus-derived carbon $^{[26]}$ & - & - & $174 \mathrm{~F} \mathrm{~g}^{-1}$ & 2200 & $0.4-0.6$ \\
\hline
\end{tabular}

carbonization temperatures. Moreover, except for large surface area and micropore volume, the dopant $\mathrm{N}, \mathrm{O}$, and other functional groups can also highly improve the electrochemical performance of the carbon materials.

Moreover, the electrochemical performance of charcoal $\mathrm{C}$ is compared with the other wood-based electrodes prepared by

Table 5. Electrochemical performance of various wooden electrodes.

\begin{tabular}{|c|c|c|c|}
\hline Wooden electrodes & $\begin{array}{c}\text { Discharge capacity/ } \\
\text { capacitance } \\
{\left[\mathrm{mAh} \mathrm{g}^{-1}\right]}\end{array}$ & $\begin{array}{l}\text { Electrical } \\
\text { conductivity } \\
{\left[\mathrm{S} \mathrm{m}^{-1}\right]}\end{array}$ & $\begin{array}{l}\text { Charge-discharge } \\
\text { cycling stability }\end{array}$ \\
\hline Lignosulfonate/graphite $e^{[4]}$ & 35 & 280 & $\begin{array}{l}80 \% \text { retention after } \\
1000 \text { cycles at } 4 \mathrm{~A} \mathrm{~g}^{-1}\end{array}$ \\
\hline Humic acid/graphite $^{[5]}$ & 20 & 50 & $\begin{array}{l}84 \% \text { retention after } \\
1000 \text { cycles at } 1 \mathrm{~A} \mathrm{~g}^{-1}\end{array}$ \\
\hline Quercus ilex bark/graphite ${ }^{[7]}$ & 20 & 30 & $\begin{array}{l}68 \% \text { retention after } \\
1000 \text { cycles at } 4 \mathrm{~A} \mathrm{~g}^{-1}\end{array}$ \\
\hline Charcoal C & 90 & 0.2 & $\begin{array}{l}88 \% \text { retention after } \\
1000 \text { cycles at } 4 \mathrm{~A} \mathrm{~g}^{-1}\end{array}$ \\
\hline
\end{tabular}

our group, as shown in Table 5. Charcoal C electrode presents the highest discharge capacity and the best stability. Compared with lignosulfonate/graphite electrode, its discharge capacity increases by 2.5 times. However, the conductivity of charcoal $\mathrm{C}$ electrodes is much lower than that of other wooden electrodes.

\section{Conclusion}

In this work, we use wood charcoal as the starting materials to fabricate electrodes for electrical energy storage. A mechanochemical ball-milling method is developed for the fabrication of charcoal electrodes, with protein nanofibrils as binders. The charcoal electrode displays a capacitance of $90 \mathrm{mAhg}^{-1}$ and a conductivity of $0.2 \mathrm{~S} \mathrm{~m}^{-1}$. The quinone groups in the charcoal help improve the discharge capacity.

Charcoals as sustainable, low-cost, simply produced biomass materials are promising for large-scale production of energy storage in supercapacitors. Compared with active carbon materials, the absence of higher temperatures, and of processing steps to add and remove activation agents, in forming charcoal, further 
argues the sustainability relevance of this mode of materials preparation.

\section{Experimental Section}

Chemical and Reagents: Graphite (flakes, mp $3652-3697^{\circ} \mathrm{C}$, density $\left.1.9 \mathrm{~g} \mathrm{~cm}^{-3}\right)$, perchloric acid $\left(\mathrm{HClO}_{4}\right.$, Sigma-Aldrich, Steinheim, Germany), hydrochloric acid $(\mathrm{HCl}$, Sigma-Aldrich, Saint Louis, MO, USA), $\mathrm{KBr}$ (Scharlau, Barcelona, Spain), and lysozyme from hen egg white (Sigma-Aldrich, Mannheim, Germany) were used as received. Charcoal materials were collected from the charcoal kiln located in Godegård, Östergötland, Sweden, 2019. The hen egg-white lysozyme protein nanofibril dispersion $\left(10 \mathrm{mg} \mathrm{mL}^{-1}, \mathrm{pH}\right.$ 1.6) was prepared by dissolving the lysozyme into $25 \mathrm{mM} \mathrm{HCl}$, followed by heating to $80^{\circ} \mathrm{C}$ for $72 \mathrm{~h}$ under magnetic stirring.

Mechanical Grinding: The ball-milling process was run on a mixer mill MM400 (Retsch, Haan, Germany), with a stainless steel cup of $1.5 \mathrm{~mL}$ mounted. Amount of the charcoal materials and 20 stainless steel milling balls $(2.2 \mathrm{~g})$ were added into the milling cup, which was shaken at $30 \mathrm{~Hz}$ for $99 \mathrm{~min}$. Thereafter, $0.5 \mathrm{~mL}$ of the protein nanofibril dispersion was added into the charcoal materials, and the milling cup was shaken for another $99 \mathrm{~min}$. A charcoal paste was collected.

Electrode Fabrication: The generated charcoal paste was painted on top of gold substrates via a blade coater (a ZFR 2040 film applicator, Erichsen 510 , Hemer, Germany) at a speed of $20 \mathrm{~mm} \mathrm{~s}^{-1}$, and then the electrodes were dried at $100^{\circ} \mathrm{C}$ for $15 \mathrm{~min}$.

Elemental Composition and the Nature of Charcoal: The charcoal materials were collected directly from the charcoal producing site, and the raw charcoal samples were sent to Measur Oy, Helsinki, Finland. The elemental composition was analyzed using Dumas combustion method for CHNS analysis and Unterzaucher pyrolysis method for $\mathrm{O}$ analysis, using ICP-OES for $\mathrm{P}, \mathrm{K}, \mathrm{Ca}, \mathrm{Cu}, \mathrm{Mg}, \mathrm{Si}, \mathrm{Fe}$, and $\mathrm{Zn}$ analyses, and ICP-MS for $\mathrm{Pb}$ analysis.

Electrochemical Measurements: The electrochemical measurements were recorded via a standard three-electrode configuration (Bioanalytical Systems Inc., West Lafayette, IN, USA), with a platinum plate as counter electrode (CE), $\mathrm{Ag} / \mathrm{AgCl}$ (saturate $\mathrm{KCl}$ salt) as reference electrode (RE), and gold (evaporated onto a silicon wafer 4" $(1,0,0)$ ) coating with charcoal paste as working electrode (WE). The CV and galvanostatic charge-discharge measurements were performed on an autolab PGStat 10 (EchoChemie, the Netherlands), with $0.1 \mathrm{M} \mathrm{HClO}_{4}$ as electrolyte. For the $\mathrm{CV}$ measurements at different $\mathrm{pH}, \mathrm{HClO}_{4}$ with different concentrations was used.

The discharge capacity of the charcoal electrodes is calculated by

$Q=I \Delta t / m$

where $Q$ is the discharge capacity, $I$ is the charge-discharge current, $\Delta t$ is the discharge time, and $m$ is the mass of the electrodes.

Fourier Transform Infrared Spectroscopy: FTIR spectra of the charcoal materials were generated via a VERTEX (Bruker, USA) at room temperature, in transmittance mode. The charcoal materials were ground with $\mathrm{KBr}$ and pressed into $\mathrm{KBr}$ pellets before doing the measurements.

Raman Spectroscopy: The Raman spectroscopy measurements were performed via a Raman instrument equipped with a spectrograph (Kymera), a microscope (Nikon eclipse Ti), and a $50 \times$ air objective with LEICA N.A. 0.75. A thermoelectrically cooled EMCCD camera $\left(-60^{\circ} \mathrm{C}\right.$, Newton, Andor) and an excitation laser wavelength of $532 \mathrm{~nm}$ and power of $25 \mathrm{~mW}$ were utilized. An integration time of $5 \mathrm{~s}$ on Andersolis software was used for the Raman signal recording, in six random areas of the samples. The acquired six spectra were averaged, smoothed, and baseline corrected.

X-Ray Diffraction: A PANalytical X'Pert diffractometer with $\mathrm{Cu} \mathrm{K \alpha}$ radiation ( $45 \mathrm{kV}$ and $40 \mathrm{~mA}$ ) was used for the XRD measurement, with the charcoal materials painted onto Si substrates.
Scanning Electron Microscopy: The SEM images of the charcoal electrodes were collected from Zeiss Leo 1550 Gemini scanning electron microscope with an acceleration voltage of $5 \mathrm{kV}$ (Zeiss, Germany).

Transmission Electron Microscopy: The TEM images were acquired in Talos L120C microscope (Thermo Fisher Scientific, Brno, Czech Republic) operating at $120 \mathrm{kV}$. The images were recorded with a Ceta-D camera.

Nitrogen Physisorption: Nitrogen adsorption/desorption isotherms were recorded at $77 \mathrm{~K}$ using an ASAP2020 (Micromeritics). The materials were degassed at $300^{\circ} \mathrm{C}$ for $6 \mathrm{~h}$ prior to the analysis. The specific surface area was calculated using the Brunauer-Emmet-Teller (BET) equation at a $P / P_{0}=0.01-0.08$, the micropore volume was calculated using the t-plot method at $t=0.5-0.9 \mathrm{~nm}$, and the pore size distribution was calculated from the desorption isotherm using the Barrett-Joyner-Halenda $(\mathrm{BJH})$ method.

\section{Supporting Information}

Supporting Information is available from the Wiley Online Library or from the author.

\section{Acknowledgements}

This work was funded by the Knut and Alice Wallenberg Foundation (KAW) via a Wallenberg Scholar grant to O.I. The authors thankfully acknowledge the Swedish Government Strategic Research Area in Materials Science on Functional Materials at Linköping University (Faculty Grant SFO-Mat-LiU No 2009 00971) for financial support.

\section{Conflict of Interest}

O.I. has ownership in the company Ligna Energy AB developing biopolymer hybrid electrodes for charge storage.

\section{Data Availability Statement}

The data that support the findings of this study are available in the supplementary material of this article.

\section{Keywords}

Biomass, carbon, charcoal, organic electrodes, quinones

Received: December 9, 2021 Published online:

[1] a) S. Admassie, A. Elfwing, E. W. Jager, Q. Bao, O. Inganäs, J. Mater. Chem. A 2014, 2, 1974; b) O. Inganäs, S. Admassie, Adv. Mater. 2014, 26, 830; c) F. Ajjan, N. Casado, T. Rębiś, A. Elfwing, N. Solin, D. Mecerreyes, O. Inganäs, J. Mater. Chem. A 2016, 4, 1838; d) F. Ajjan, M. Jafari, T. Rębiś, T. Ederth, O. Inganäs, J. Mater. Chem. A 2015, 3, 12927; e) F. N. Ajjan, M. Vagin, T. Rębiś, L. E. Aguirre, L. Ouyang, O. Inganäs, Adv. Sustain. Syst. 2017, 1, 1700054 ; f) J. Edberg, O. Inganäs, I. Engquist, M. Berggren, J. Mater. Chem. A 2018, 6, 145; g) C. Liedel, X. Wang, M. Antonietti, Nano Energy 2018, 53, 536; h) T. Y. Nilsson, M. Wagner, O. Inganäs, ChemSusChem 2015, 8, 4081.

[2] G. Milczarek, O. Inganäs, Science 2012, 335, 1468.

[3] M. Wagner, T. Rębiś, O. Inganäs, J. Power Sources 2016, 302, 324. 
[4] L. Liu, N. Solin, O. Inganäs, RSC Adv. 2019, 9, 39758.

[5] L. Liu, N. Solin, O. Inganäs, Materials 2019, 12, 4032.

[6] B. Zhou, J. Li, W. Liu, H. Jiang, S. Li, L. Tan, L. Dong, L. She, Z. Wei, ChemSusChem 2020, 13, 2628.

[7] L. Liu, L. Wang, N. Solin, O. Inganäs, Adv. Mater. Technol. 2021, 2001042.

[8] a) S. Chaleawlert-umpon, T. Berthold, X. Wang, M. Antonietti, C. Liedel, Adv. Mater. Interfaces 2017, 4, 1700698; b) S. Chaleawlert-umpon, C. Liedel, J. Mater. Chem. A 2017, 5, 24344 ; c) I. K. Ilic, M. Meurer, S. Chaleawlert-umpon, M. Antonietti, C. Liedel, RSC Adv. 2019, 9, 4591; d) U. Ail, J. Phopase, J. Nilsson, Z. U. Khan, O. Inganäs, M. Berggren, X. Crispin, ACS Sustain. Chem. Eng. 2020, 8, 17933; e) I. K. Ilic, K. Leus, J. Schmidt, J. Hwang, M. Maranska, S. Eigler, C. Liedel, ACS Sustain. Chem. Eng. 2020, 8, 3055; f) I. K. Ilic, A. Tsouka, M. Perovic, J. Hwang, T. Heil, F. F. Loeffler, M. Oschatz, M. Antonietti, C. Liedel, Adv. Sustain. Syst. 2021, 5, 2000206.

[9] a) L. Chen, Z. Chen, Y. Kuang, C. Xu, L. Yang, M. Zhou, B. He, M. Jing, Z. Li, F. Li, ACS Appl. Mater. Interfaces 2018, 10, 27047; b) Y. Lu, J. Chen, Nat. Rev. Chem. 2020, 4, 127; c) P. Poizot, J. Gaubicher, S. Renault, L. Dubois, Y. Liang, Y. Yao, Chem. Rev. 2020, 120, 6490 .

[10] M. Miroshnikov, in ProQuest Dissertations Publishing, 2020.

[11] a) S. Admassie, F. Ajjan, A. Elfwing, O. Inganäs, Mater. Horizons 2016, 3, 174; b) F. N. Ajjan, D. Mecerreyes, O. Inganäs, Biotechnol. J. 2019, 14, 1900062; c) C. Liedel, ChemSusChem 2020, 13, 2110; d) L. Liu, N. Solin, O. Inganäs, Adv. Energy Mater. 2021, 2003713.

[12] a) A. M. Navarro-Suarez, D. Saurel, P. Sanchez-Fontecoba, E. Castillo-Martinez, J. Carretero-González, T. Rojo, J. Power Sources 2018, 397, 296; b) Z. Tian, Y. Zhang, J. Zhu, Q. Li, T. Liu, M. Antonietti, Adv. Energy Mater. 2021, 2102489; c) H. Lu, F. Ai, Y. Jia, C. Tang, X. Zhang, Y. Huang, H. Yang, Y. Cao, Small 2018,
14, 1802694; d) A. Pozio, A. Aurora, P. Prosini, J. Power Sources 2020, 449, 227555.

[13] A. Adamson, R. Väli, M. Paalo, J. Aruväli, M. Koppel, R. Palm, E. Härk, J. Nerut, T. Romann, E. Lust, A. Jänes, RSC Adv. 2020, 10, 20145.

[14] a) A. Jain, R. Balasubramanian, M. Srinivasan, Chem. Eng. J. 2016, 283, 789; b) T. Tay, S. Ucar, S. Karagöz, J. Hazard. Mater. 2009, 165, 481.

[15] P. J. Hall, M. Mirzaeian, S. I. Fletcher, F. B. Sillars, A. J. Rennie, G. O. Shitta-Bey, G. Wilson, A. Cruden, R. Carter, Energy Environ. Sci. 2010, 3, 1238.

[16] M. J. Antal, M. Grønli, Indust. Eng. Chem. Res. 2003, 42, 1619.

[17] A. Volta, J. Banks, Philos. Mag. 1800, 7, 289.

[18] F. Shen, W. Luo, J. Dai, Y. Yao, M. Zhu, E. Hitz, Y. Tang, Y. Chen, V. L. Sprenkle, X. Li, Adv. Energy Mater. 2016, 6, 1600377.

[19] T. S. Blankenship II, N. Balahmar, R. Mokaya, Nat. Commun. 2017, 8,1 .

[20] R. Muktham, A. S. Ball, S. K. Bhargava, S. Bankupalli, Energy Sci. Eng. 2016, 4, 86 .

[21] a) L. Costa, A. F. Fonseca, F. V. Pereira, J. I. Druzian, Cell Chem Technol. 2015, 49, 127; b) H. Yang, R. Yan, H. Chen, D. H. Lee, C. Zheng, Fuel 2007, 86, 1781.

[22] G. Milczarek, M. Nowicki, Mater. Res. Bull. 2013, 48, 4032.

[23] M. Quan, D. Sanchez, M. F. Wasylkiw, D. K. Smith, J. Am. Chem. Soc. 2007, 129, 12847.

[24] H. Zhang, Y. Zhang, L. Bai, Y. Zhang, L. Sun, J. Mater. Chem. A 2021, 9, 12521.

[25] S.-H. Wang, Y.-K. Hwang, S. W. Choi, X. Yuan, K. B. Lee, F.-C. Chang, J. Taiwan Inst. Chem. Eng. 2020, 115, 315.

[26] Y. Zhang, S. Liu, X. Zheng, X. Wang, Y. Xu, H. Tang, F. Kang, Q. H. Yang, J. Luo, Adv. Funct. Mater. 2017, 27, 1604687. 